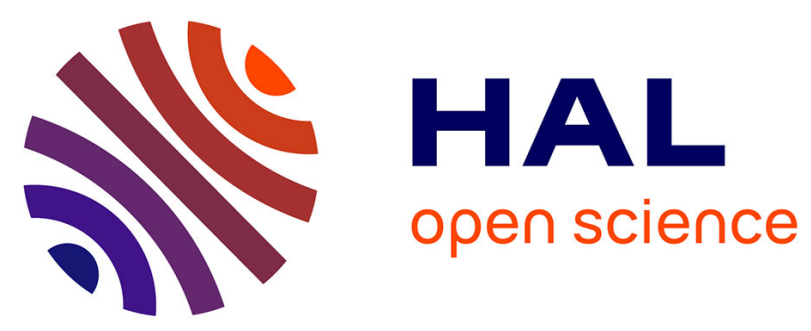

\title{
Patterns of genetic structure among Hawaiian corals of the genus Pocillopora yield clusters of individuals that are compatible with morphology.
}

Jean-François Flot, Hélène Magalon, Corinne Cruaud, Arnaud Couloux, Simon Tillier

\section{To cite this version:}

Jean-François Flot, Hélène Magalon, Corinne Cruaud, Arnaud Couloux, Simon Tillier. Patterns of genetic structure among Hawaiian corals of the genus Pocillopora yield clusters of individuals that are compatible with morphology.. Comptes Rendus Biologies, 2008, 331 (3), pp.239-47. 10.1016/j.crvi.2007.12.003 . hal-00941654

\section{HAL Id: hal-00941654 \\ https://hal.science/hal-00941654}

Submitted on 4 May 2016

HAL is a multi-disciplinary open access archive for the deposit and dissemination of scientific research documents, whether they are published or not. The documents may come from teaching and research institutions in France or abroad, or from public or private research centers.
L'archive ouverte pluridisciplinaire HAL, est destinée au dépôt et à la diffusion de documents scientifiques de niveau recherche, publiés ou non, émanant des établissements d'enseignement et de recherche français ou étrangers, des laboratoires publics ou privés. 
Evolution / Évolution

\title{
Patterns of genetic structure among Hawaiian corals of the genus Pocillopora yield clusters of individuals that are compatible with morphology
}

\author{
Jean-François Flot ${ }^{\mathrm{a}, *}$, Hélène Magalon ${ }^{\mathrm{b}},{\text { Corinne } \text { Cruaud }^{\mathrm{c}} \text {, Arnaud Couloux }}^{\mathrm{c}}$, \\ Simon Tillier ${ }^{a}$ \\ ${ }^{a}$ UMR UPMC-CNRS-MNHN-IRD 7138, département 'Systématique et évolution', Muséum national d'histoire naturelle, CP 26, \\ 57, rue Cuvier, 75231 Paris cedex 05, France \\ b EPHE, UMR CNRS 7625, laboratoire 'Fonctionnement et évolution des systèmes écologiques', université Pierre-et-Marie-Curie, \\ 7, quai Saint-Bernard, 75005 Paris, France \\ ${ }^{\mathrm{c}}$ GENOSCOPE, Centre national de séquençage, 2, rue Gaston-Crémieux, CP 5706, 91057 Evry cedex, France
}

\begin{abstract}
Six variable sequence markers are developed and analyzed to find out species boundaries in Hawaiian corals of the genus Pocillopora: the putative mitochondrial control region; a recently discovered, hypervariable mitochondrial open reading frame; the internal transcribed spacer 2 (ITS2), located in the nuclear ribosomal DNA; three nuclear introns of calmodulin, elongation factor- $1 \alpha$ and the ATP synthase $\beta$ subunit. Using the first two markers, we identify five distinct mitochondrial lineages and these lineages are compatible with morphology. The situation is more complex with nuclear markers since more than two haplotypes are observed in some individuals. To detect clusters of individuals, haplotype networks are constructed with additional connections drawn between co-occurring haplotypes to delineate potential fields for recombination: few clusters of nuclear haplotypes are found to correspond to clusters of individuals, but those that are detected (mostly in the ITS2 dataset) are also compatible with morphology.
\end{abstract}

\section{Résumé}

La structuration génétique des coraux du genre Pocillopora à Hawaii délimite des groupes d'individus compatibles avec la morphologie. Six marqueurs de séquence variables sont développés et analysés pour déterminer les frontières interspécifiques chez les coraux du genre Pocillopora à Hawaii : la région de contrôle putative, une région codante mitochondriale hypervariable, le deuxième espaceur ribosomique (ITS2) et trois introns nucléaires des gènes de la calmoduline, du facteur d'élongation- $1 \alpha$ et de la sous-unité $\beta$ de l'ATP synthétase. Les deux premiers marqueurs nous permettent d'identifier cinq lignées mitochondriales distinctes et compatibles avec la morphologie. La situation est plus complexe pour les marqueurs nucléaires, puisque plus de deux haplotypes sont observés chez certains individus. Afin de détecter les groupes d'individus, nous construisons des réseaux d'haplotypes sur lesquels nous délimitons des champs de recombinaison potentiels en reliant par des connections supplémentaires

\footnotetext{
* Corresponding author.

E-mail address: jfflot@mnhn.fr (J.-F. Flot).
} 
les haplotypes trouvés en cooccurrence : peu de groupes d'haplotypes nucléaires correspondent à des groupes d'individus, mais les groupes d'individus détectés (pour la plupart dans le jeu de données ITS2) sont aussi compatibles avec la morphologie.

\section{Introduction}

Delimitation and identification of coral species is rendered difficult by intra- and interpopulational morphological variations that are often similar in range to, or even greater than, differences between currently recognized species [1]. Indeed, coral colonies are known to display phenotypic plasticity in response to "light, sedimentation, current and water agitation, temperature, depth, salinity, emersion, physical damage, predation, intra- and interspecific competition, association with other organisms, disease, substrate topography" [2], and even gravity [3]. Moreover, crossings between morphologically different corals currently considered as distinct species have been demonstrated to bring out intermediate morphologies that add to the general confusion [4].

Since it is not subject to ecophenotypic variation, the DNA of an organism is commonly used as a source of information to tell intraspecific genetic diversity and phenotypic plasticity from interspecific differences. DNA sequence markers are well suited for this purpose as they generally cross-amplify over a wide range of species, genera and families: the mitochondrial coxl gene, in particular, can be amplified consistently from most living creatures by using universal primers [5] and has been proposed as a reference marker for the 'barcoding of life' [6]. The nuclear, ribosomal internal transcribed spacers (ITS) are also widely used [7]: their presence in several hundred copies per genome makes them easy to amplify, whereas concerted evolution $[8,9]$ usually results in the presence of a single dominant ITS type per individual, with little intraspecific variation [10]. More recently, exon-primed, intron-crossing (EPIC) PCR amplification of gene introns [11-13] was proposed as a way to assess variation at several independent nuclear loci.

Coral biodiversity, however, has proved difficult to study using molecular sequence markers. Cnidarian mitochondrial DNA seems to evolve very slowly $[14,15]$, and coxl sequences typically display little to no variability among congeneric corals [16,17], whereas in Acropora the presence of silenced, mutation-prone ITS pseudogenes [18] as well as of ancestrally shared lineages [19] has cast doubt on the utility of ribosomal DNA for coral species delimitation. As for EPIC-PCR, its application to corals has been limited until now to Acropora [4,20,21] and Montipora [22] and has yet to provide the basis for a taxonomic revision of these genera.

In the discussion surrounding scleractinian coral species delimitation, corals of the genus Pocillopora are of special interest due to their spectacular, supposedly intraspecific morphological variations [23]. Species boundaries in this group are poorly understood, and the resulting taxonomic uncertainties undermine the numerous physiological and ecological studies conducted on these keystone organisms. Previous attempts to develop variable molecular sequence markers in this group have been largely unsuccessful [16,24,25], except for the second internal transcribed spacer (ITS2) [26,27]. The present article reports the development of five other variable sequence markers in Pocillopora: two regions identified as the most variable in the mitochondrial genome of Pocillopora (the putative D-loop and an open reading frame of unknown function) [28], and three nuclear EPIC markers (an intron of calmodulin, an intron of elongation factor- $1 \alpha$ and an intron of the nuclear gene encoding the $\beta$ subunit of the mitochondrial ATP synthase). All six markers (including ITS2) were then tested on a set of Hawaiian coral samples attributed to five different morphospecies in order to assess their utilities and draw guidelines for future studies.

\section{Materials and methods}

Thirty-seven small coral fragments were sampled at Kaneohe Bay, Kahe Point, and Moku Manu in Oahu from colonies identified as Pocillopora damicornis Linnaeus 1758, Pocillopora eydouxi Milne Edwards and Haime 1860, Pocillopora ligulata Dana 1846, Pocillopora meandrina Dana 1846 and Pocillopora molokensis Vaughan 1907 by the first author based on their morphology (Table 1). In Hawaii, unlike other Indo-Pacific localities, visual identification of Pocillopora morphospecies poses little difficulty, and individuals of dubious 
Table 1

List of samples showing morphology, sampling location and number of haplotypes for each marker

\begin{tabular}{|c|c|c|c|c|c|c|c|c|}
\hline \multirow[t]{2}{*}{ Sample } & \multirow[t]{2}{*}{ Morphotype } & \multirow[t]{2}{*}{ Location } & \multicolumn{6}{|c|}{ Number of haplotypes } \\
\hline & & & ORF & & ITS2 & $2 \mathrm{Calm}$ & $\mathrm{EF}-$ & $1 \alpha \operatorname{ATPS} \beta$ \\
\hline 1 & P. damicornis & $\mathrm{KB}$ & 1 & 1 & 1 & 2 & 2 & 1 \\
\hline 2 & - & - & 1 & 1 & 1 & 2 & 2 & 2 \\
\hline 3 & - & - & 1 & 1 & 2 & $\underline{4}$ & $\underline{\mathbf{3}}$ & $\underline{\mathbf{3}}$ \\
\hline 4 & - & - & 1 & 1 & 1 & $\underline{4}$ & 2 & $\underline{\mathbf{3}}$ \\
\hline 5 & - & - & 1 & 1 & 2 & $\underline{\mathbf{3}}$ & 2 & $\underline{\overline{\mathbf{3}}}$ \\
\hline 6 & - & - & 1 & 1 & $\underline{\mathbf{3}}$ & 2 & 2 & 2 \\
\hline 7 & - & - & 1 & 1 & 2 & $\underline{\mathbf{3}}$ & $\underline{\mathbf{5}}$ & 2 \\
\hline 8 & - & - & 1 & 1 & 2 & $\overline{2}$ & $\overline{1}$ & 2 \\
\hline 9 & - & - & 1 & 1 & 1 & 2 & 2 & 1 \\
\hline 10 & - & - & 1 & 1 & 1 & 2 & 2 & 2 \\
\hline 11 & - & - & 1 & 1 & 2 & 2 & 2 & 1 \\
\hline 12 & - & - & 1 & 1 & 2 & 2 & 1 & 2 \\
\hline 13 & - & - & 1 & 1 & 2 & $\underline{\mathbf{3}}$ & 2 & 2 \\
\hline 14 & - & - & 1 & 1 & 2 & 2 & 2 & 1 \\
\hline 15 & - & - & 1 & 1 & 2 & 2 & 2 & 2 \\
\hline 16 & - & - & 1 & 1 & 1 & 2 & 1 & 2 \\
\hline 17 & P. meandrina & - & 1 & 1 & 2 & 2 & 1 & 2 \\
\hline 18 & - & - & 1 & 1 & 2 & 2 & 2 & 2 \\
\hline 19 & - & - & 1 & 1 & 2 & 2 & $\underline{\mathbf{3}}$ & 2 \\
\hline 20 & - & - & 1 & 1 & 2 & 2 & $\underline{\mathbf{3}}$ & 2 \\
\hline 21 & - & - & 1 & 1 & 2 & 2 & $\underline{\mathbf{3}}$ & 2 \\
\hline 22 & - & - & 1 & 1 & 2 & 2 & 2 & 2 \\
\hline 23 & - & - & 1 & 1 & 2 & 1 & 2 & 2 \\
\hline 24 & P. ligulata & - & 1 & 1 & 2 & 2 & 2 & 2 \\
\hline 25 & - & - & 1 & 1 & 2 & 1 & 2 & 1 \\
\hline 26 & - & - & 1 & 1 & 2 & 1 & 2 & 1 \\
\hline 27 & - & - & 1 & 1 & 1 & 1 & 2 & 1 \\
\hline 28 & - & - & 1 & 1 & 2 & 2 & 2 & 2 \\
\hline 29 & - & - & 1 & 1 & 2 & 1 & 2 & 2 \\
\hline 30 & P. eydouxi & $\mathrm{KP}$ & 1 & 1 & 2 & 2 & 1 & 2 \\
\hline 31 & - & - & 1 & 1 & 2 & 2 & 1 & 1 \\
\hline 32 & - & - & 1 & 1 & 2 & 2 & 1 & 1 \\
\hline 33 & P. molokensis & MM & 1 & 1 & 2 & 2 & 1 & 2 \\
\hline 34 & - & - & 1 & 1 & 1 & 2 & 1 & 2 \\
\hline 35 & - & - & 1 & 1 & 2 & 2 & 2 & 1 \\
\hline 36 & - & - & 1 & 1 & 2 & 2 & 2 & 2 \\
\hline 37 & - & - & 1 & 1 & 2 & 2 & $\underline{4}$ & 2 \\
\hline
\end{tabular}

Numbers of haplotypes higher than 2 are shown in bold letters. Location codes: KB, Kaneohe Bay $\left(21^{\circ} 26^{\prime} \mathrm{N} 157^{\circ} 47^{\prime} \mathrm{W}\right)$; KP, Kahe Point $\left(21^{\circ} 19^{\prime} \mathrm{N} 158^{\circ} 07^{\prime} \mathrm{W}\right)$; MM, Moku Manu $\left(21^{\circ} 28^{\prime} \mathrm{N} 157^{\circ} 43^{\prime} \mathrm{W}\right)$.

or intermediary morphologies are rarely observed. To avoid mistaking small $P$. eydouxi colonies for $P$. meandrina, only large colonies of $P$. eydouxi were sampled. Genomic DNA was purified directly from fresh samples using the Wizard Genomic DNA Extraction kit (Promega).

As these coral DNA extracts also contained DNA from zooxanthellae and possibly bacteria, coral-specific primers (Table 2) were defined with the help of Primer3 [29] based on alignments of coral, human, bacterial and dinoflagellate sequences (whenever available) obtained from GenBank. Each marker was amplified in $25-\mu 1$
Table 2

List of primers used for PCR amplification

\begin{tabular}{lll}
\hline Marker & Primer name & Primer sequence \\
\hline ORF & FATP6.1 & $5^{\prime}$-TTTGGGSATTCGTTTAGCAG-3' \\
& RORF & $5^{\prime}$-SCCAATATGTTAAACASCATGTCA-3' \\
CR & FNAD5.2deg & $5^{\prime}$-GCCYAGRGGTGTTGTTCAAT-3' \\
& RCOI3 & $5^{\prime}$-CGCAGAAAGCTCCAATCGTA-3' \\
ITS2 & ITSc2-5 & $5^{\prime}$-AGCCAGCTGCGATAAGTAGTG-3' \\
& R28S1 & $5^{\prime}$-GCTGCAATCCCAAACAACCC-3' \\
Calm & FCalmPoc & $5^{\prime}$-TGAGGTTGATGCTGATGGTATG-3' \\
& RCalmInt & $5^{\prime}$-GAAATCAATTGTTCCATTACCTG-3' \\
EF-1 $\alpha$ & FefIntr2 & $5^{\prime}$-TTACCGGTACTTCACAGTTAAGAC-3' \\
& RefPoc1 & $5^{\prime}$-TCACCAGTACCAGCAGCAAC-3' \\
ATPS $\beta$ & ATPS $\beta$ f2 & $5^{\prime}$-TGAAAGACAAGAGCTCCAAGGTA-3' \\
& ATPS $\beta$ r2 & $5^{\prime}$-GGTTCGTTCATCTGACCATACAC-3' \\
\hline
\end{tabular}

ORF: mitochondrial open-reading frame; $\mathrm{CR}$ : putative mitochondrial control region; ITS2: internal transcribed spacer 2; Calm: calmodulin; EF- $1 \alpha$ : elongation factor- $1 \alpha$; ATPS $\beta$ : ATP synthase $\beta$ subunit.

reaction mixes containing $20 \mu \mathrm{H}_{2} \mathrm{O}, 2.5 \mu \mathrm{l}$ Red Taq buffer (Sigma), $1 \mu \mathrm{l}$ dNTP mix (6.6 $\mathrm{mmoll}^{-1}$ total), $1.3 \mu \mathrm{l}$ DMSO, $0.3 \mu \mathrm{l}$ primers $\left(25 \mu \mathrm{moll}^{-1}\right), 0.3 \mu \mathrm{l}$ Red Taq (Sigma) and $0.5 \mu \mathrm{l}$ undiluted DNA extract (containing about $15 \mathrm{ng}$ of total DNA). PCR conditions comprised an initial denaturation step of $60 \mathrm{~s}$ at $94^{\circ} \mathrm{C}$, followed by 40 cycles $\left(30 \mathrm{~s}\right.$ denaturation at $94^{\circ} \mathrm{C}, 30 \mathrm{~s}$ annealing at $53{ }^{\circ} \mathrm{C}, 75 \mathrm{~s}$ elongation at $72{ }^{\circ} \mathrm{C}$ ) and a final 5-min elongation step at $72^{\circ} \mathrm{C}$. PCR products were cleaned using a mix of exonuclease I and shrimp alkaline phosphatase and sequenced in both directions with the same primers as for amplification. Sequences were assembled and cleaned using Sequencher 4 (Gene Codes).

PCR amplification products obtained from nuclear markers frequently contained more than a single sequence type (Table 1). Mixed sequences were disentangled by direct phase extraction [30] with the help of Champuru v1.0 [31], (available online at http://134.157. $186.185 /$ champuru) when they differed in length, by interindividual comparison [32] when they had identical lengths, and by resequencing using haplotype-specific internal primers [33,34] whenever the two previous methods yielded ambiguous or uncertain results.

All sequences obtained in this study were deposited in GenBank (accession numbers EU374225EU374581). For each marker, sequences were imported into MEGA3 [35] and aligned by eye without difficulty. Sequences alignments were converted into the Roehl format using DnaSP [36], and haplotype networks were constructed using the median-joining algorithm [37] implemented in Network 4.1 (available online at http://www.fluxus-engineering.com/).

For mitochondrial DNA, clusters of haplotypes were delimited somewhat arbitrarily by grouping together 
haplotypes separated by a single mutation step. A different method was used for the nuclear markers: in order to detect clusters of haplotypes corresponding to clusters of individuals, connections between haplotypes found co-occurring in a coral colony were added as curves on the median-joining networks. This is analogous to the proposal by Doyle [38] to consider a group of individuals sharing a common pool of alleles as a 'field for recombination' [39] (FFR), i.e., a species-level population unit; with the difference that, in the present case, not all co-occurring haplotypes of a given marker may have the potential to recombine, since it is unclear whether they are orthologous or paralogous sequences (which is also the reason why we call them haplotypes, and not alleles). In the graphical representation introduced here, clusters of haplotypes that correspond to clusters of individuals stand out as having a single connection to the rest of the network: each such cluster of individuals comprises one or several FFRs, but FFRs can be found that are not part of any cluster (see figures).

\section{Results and discussion}

\subsection{Mitochondrial markers yield clusters of individuals that are compatible with morphology}

As expected for mitochondrial markers in the absence of recombination, haplotype networks obtained for the open reading frame and for the putative control region are congruent and only the network resulting from the concatenation of both markers is presented here (Fig. 1). A total of seven haplotypes are detected: a single haplotype specific of $P$. molokensis, two closely related haplotypes (separated by a single mutation) specific of $P$. ligulata, two closely related haplotypes (separated by a single mutation) for corals of the $P$. eydouxi and $P$. meandrina morphotypes and two not-so-closely related haplotypes (separated by 8 mutations) for corals of the $P$. damicornis morphotype.

P. molokensis and P. ligulata corals fall in two distinct clusters, whereas a single cluster comprises all individuals of the $P$. meandrina and $P$. eydouxi morphotypes. Small colonies of $P$. meandrina and $P$. eydouxi can be difficult to distinguish in the field: our mitochondrial data suggest that these two morphotypes are either a single species or two closely related ones. Regarding $P$. damicornis, two morphological variants have been described in Hawaii with slight differences in growth form, pigmentation and reproductive timing, suggesting that they may be sympatric cryptic species [40], which could explain our observation of two divergent mitochondrial lineages; in the present study, unfortunately,

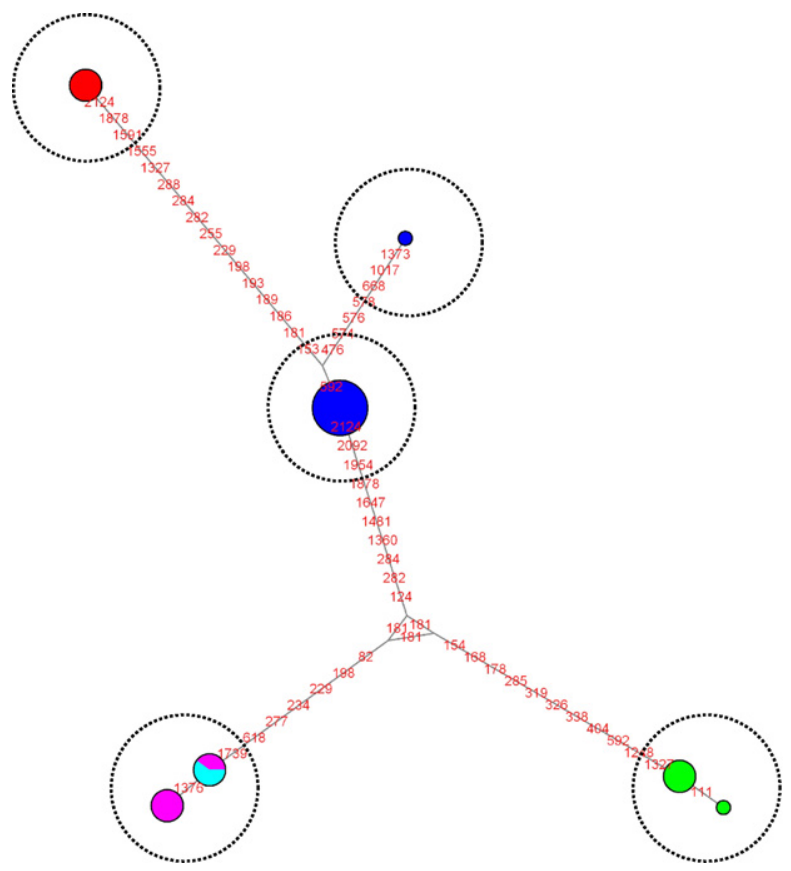

Fig. 1. Median-joining network of mitochondrial haplotypes. Coloured circles represent haplotypes and their area is proportional to the number of times a given haplotype was sampled. Colours within the circles indicate the morphotypes of the individuals in which each haplotype was detected (dark blue: P. damicornis; pink: P. meandrina; green: P. ligulata; pale blue: P. eydouxi; red: P. molokensis). Mutations are shown in red on the branches (numbers refer to positions in the alignments), and haplotype clusters are enclosed in dashed circles.

morphological details of the corals sampled were not recorded, so this hypothesis cannot be tested here.

\subsection{For all nuclear markers, more than two haplotypes are detected in some individuals}

Up to three haplotypes per coral colony are detected for ITS2 and the ATP synthase $\beta$ subunit, up to four for calmodulin, and up to five for elongation factor- $1 \alpha$ (Table 1). As haplotypes have variable lengths, the number of end peaks of a chromatogram can be used as a minimal estimate of the number of haplotypes (Fig. 2); obtaining the sequence of each haplotype, however, is the only way to determine this number, since haplotypes of identical lengths have their end peaks superimposed [30].

The occurrence of several dominant ITS types per individual is well documented in various organisms, such as oaks [41] and corals [19], and can be explained by a failure or delay in homogenization among the several hundred copies of ribosomal DNA present in a typical genome $[8,9,42]$. In the case of nuclear introns, however, the finding of more than two sequences per 

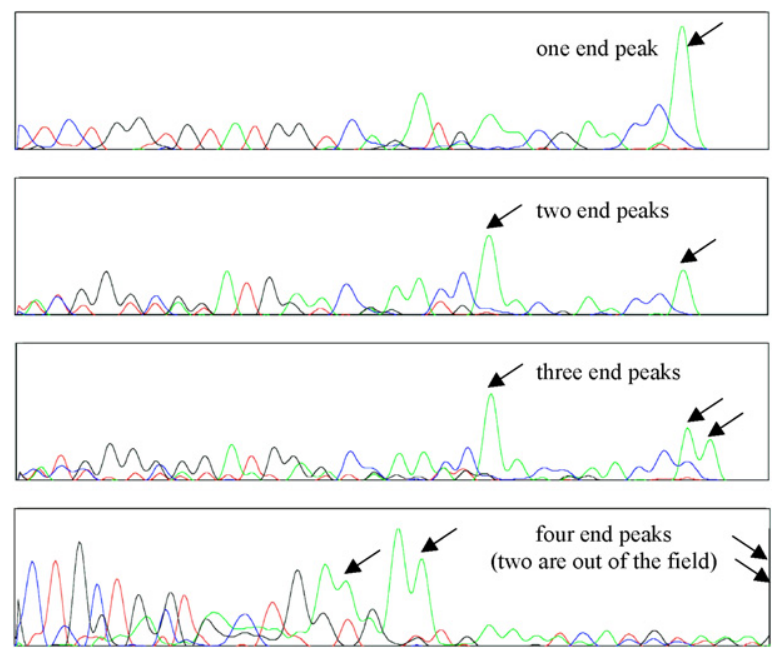

Fig. 2. Examples of traces showing variation in the number of end peaks due to different numbers of haplotypes per individual. From top to bottom: ATP synthase, sample 9; ATP synthase, sample 2; ATP synthase, sample 4; calmodulin, sample 37. All ATP synthase haplotypes end with a $\mathrm{C}$ (a A overhang is added by the polymerase during the PCR process), whereas calmodulin haplotypes end with a A that appears artefactually larger than the actual end peak.

individual comes unexpected, even though similar observations have been previously reported in periwinkles for calmodulin [43] and in Penaeus shrimps for elongation factor- $1 \alpha$ [44]. Presence of more than two gene copies in some individuals could result from gene duplication, but this explanation seems unlikely for the ATP synthase $\beta$ subunit marker, since it was shortlisted as "likely not to be member of a multigene family" by Jarman et al. [13] based on examination of the complete genomes of Homo, Caenorhabditis, and Drosophila. Moreover, our primers were designed overlapping the exon-intron boundaries for enhanced specificity and should have discriminated between paralogous gene copies, except if duplication happened recently or if concerted evolution limits divergence [45].

Other mechanisms may be responsible for the increased numbers of haplotypes observed in our study: there is no karyotypic information available for Pocillopora, but variations in chromosome numbers have been reported for corals of the genus Acropora [46,47], and a study of microsatellite inheritance using controlled crosses in Acropora palmata yielded triploid larvae possessing one paternal and two maternal alleles [48]. Chimeric colonies resulting from the fusion of two or more genetically distinct organisms have also been reported in corals of the genus Pocillopora [49,50], which may explain the high numbers of haplotypes per colony observed here. Finally, intraspecific variations in gene copy numbers have recently been discovered in humans
[51,52] and other mammals (reviewed in [53]), but it is not yet known whether such phenomenon occurs in non-mammalian organisms. In any case, our observation of more than two sequences per individual for each nuclear sequence marker investigated contrasts strongly with the results of previous studies using microsatellites in Pocillopora [54-56] that never reported the occurrence of more than two alleles in any single individual: further studies will be required to determine the reason for this discrepancy.

\subsection{Nuclear sequence markers yield clusters of individuals that are also compatible with morphology}

For ITS2 (Fig. 3), two clusters are detected that comprise more than a single individual: one includes all individuals of the $P$. ligulata morphotype, and the other all individuals of the $P$. eydouxi morphotype. In addition, two clusters of a single individual are detected, each of them of the P. damicornis morphotype. For calmodulin (Fig. 4), a single cluster of individuals is detected that comprises three samples of the $P$. meandrina morphotype. For elongation factor- $1 \alpha$ (Fig. 5), two clusters stand out, each of them made of a single $P$. eydouxi individual, whereas for the ATP synthase $\beta$ subunit (Fig. 6), only one cluster of one P. damicornis coral sample is detected.

None of these clusters comprises colonies of different morphotypes; hence, our nuclear datasets do not contradict previous morphological hypotheses, but do not support many of them either. Despite their higher variability in terms of haplotype numbers and of differences between haplotypes, nuclear markers turn out to be less informative than mitochondrial ones for delimiting clusters of individuals. The same apparent paradox is observed when comparing ITS2 and the other nuclear markers: haplotypes are fewer and less divergent for ITS2 than for calmodulin, elongation factor- $1 \alpha$ and the ATP synthase $\beta$ subunit, but nevertheless ITS2 seems to yield more clusters of individuals.

Two main hypotheses can be proposed to explain why fewer clusters of individuals are detected by using nuclear markers than by looking at mitochondrial DNA. First, it might be that individuals belonging to different mitochondrial clusters are exchanging genes through sexual reproduction; however, in that case, it would be difficult to explain why clusters of mitochondrial and nuclear haplotypes are compatible with morphology, unless some strong environmental selection is acting concomitantly on both genomes. Such selection may explain part of the molecular differences observed between $P$. damicornis and $P$. eydouxi, two morphotypes 


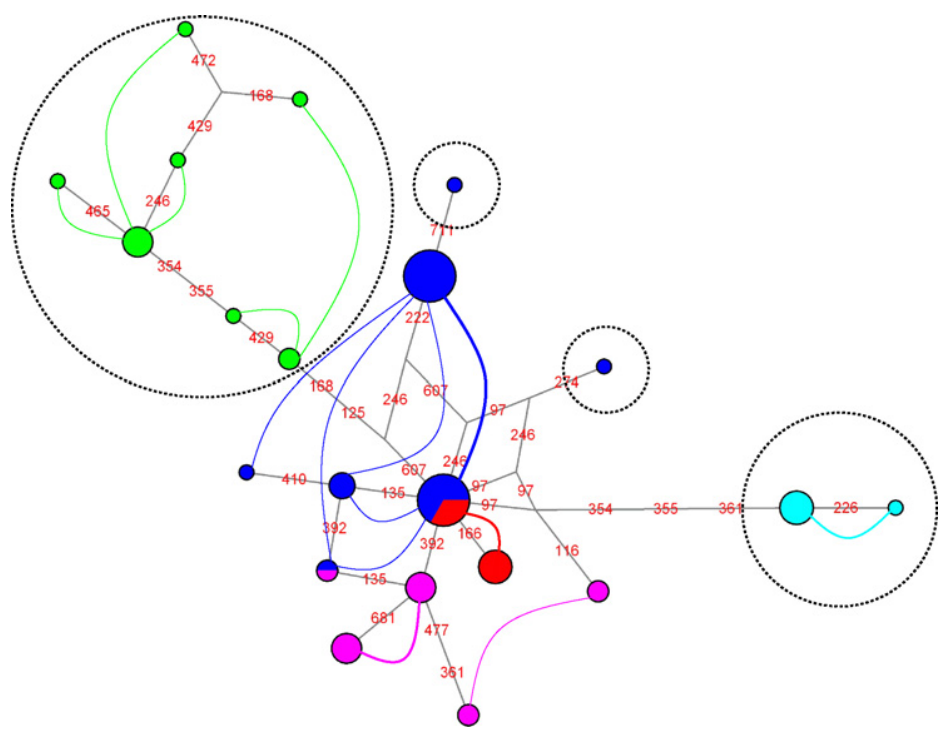

Fig. 3. Network of ITS2 haplotypes. Coloured curves connect haplotypes that co-occur in at least one individual, and their width is drawn proportional to the number of individuals in which the two haplotypes co-occur. Mutations are shown in red on the branches (numbers refer to positions in the alignments). The colour code for the curves is the same as for the haplotypes (dark blue: P. damicornis; pink: P. meandrina; green: $P$. ligulata; pale blue: P. eydouxi; red: P. molokensis). Clusters of haplotypes that correspond to clusters of individuals are enclosed in dashed circle: for instance, all $P$. ligulata haplotypes fall into one such cluster, and each of the two pools of co-occurring haplotypes observed within this cluster corresponds to a distinct potential field for recombination (FFR). The $P$. eydouxi cluster on the right side of the network comprises a single pool of co-occurring haplotypes; hence, in our dataset all individuals of the P. eydouxi morphotype are part of a single FFR.

found in contrasting reef environments in Hawaii (calm shallow waters for $P$. damicornis, deeper exposed locations for $P$. eydouxi) but not between P. ligulata and $P$. meandrina that are usually found interspersed among each other on shallow reef parts exposed to wave action.

Alternatively, second, the different mitochondrial clusters may correspond to reproductively isolated sympatric populations (i.e., biological species), in which case incomplete lineage sorting and retention of a shared ancestral polymorphism could explain why these species cannot be distinguished using nuclear intron sequences. A prediction from this second hypothesis would be that, among nuclear markers, those with shorter coalescence time due to concerted evolution, such as ITS2, should yield clearer patterns than other genes; and this is precisely what is observed here.

\section{Conclusions}

Our results show that mitochondrial data obtained by sequencing the putative control region and the recently described open reading frame can be useful for resolving interpopulational relationships among pocilloporid corals. On the other hand, nuclear markers in Pocillopora are plagued with high numbers of haplotypes in some individuals that make sequencing cumbersome and costly; moreover, these markers turn out

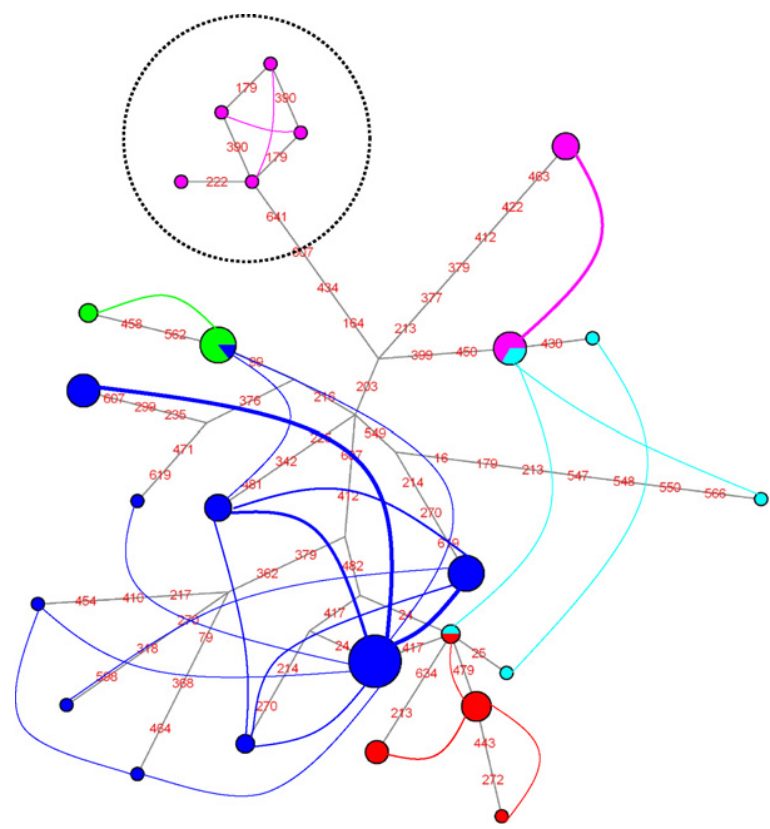

Fig. 4. Network of calmodulin haplotypes (dark blue: P. damicornis; pink: P. meandrina; green: P. ligulata; pale blue: P. eydouxi; red: P. molokensis).

not to be very informative in terms of clusters of individuals. Among nuclear markers, ITS2 provides a slightly clearer picture than nuclear gene introns, but apparently 


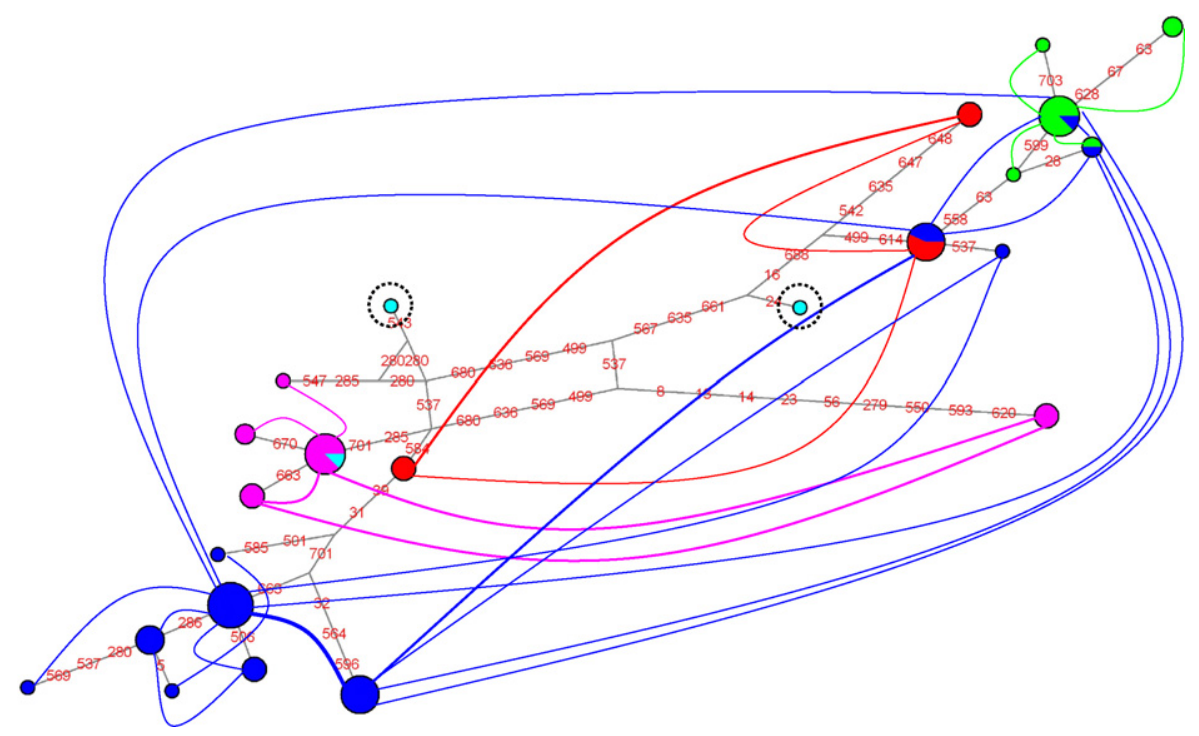

Fig. 5. Network of elongation factor-1 $\alpha$ haplotypes (dark blue: P. damicornis; pink: P. meandrina; green: P. ligulata; pale blue: P. eydouxi; red: P. molokensis).

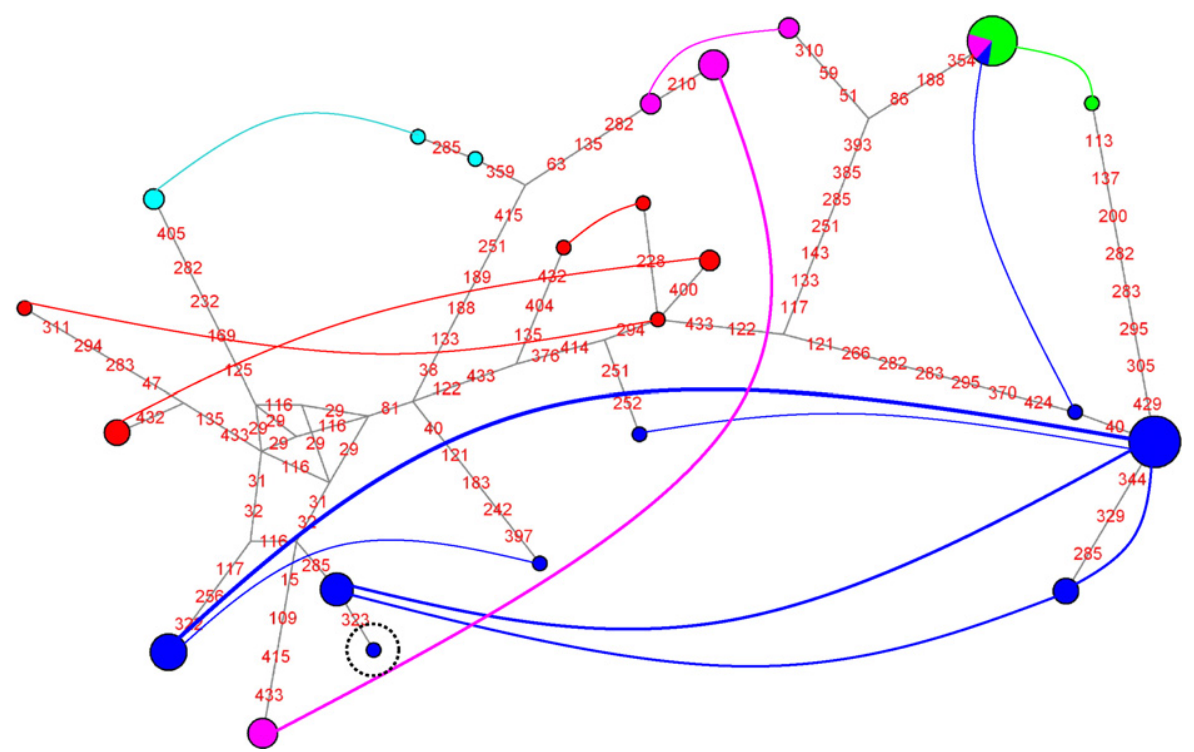

Fig. 6. Network of ATP synthase $\beta$ subunit haplotypes (dark blue: P. damicornis; pink: P. meandrina; green: P. ligulata; pale blue: P. eydouxi; red: P. molokensis).

does not resolve all potential interspecific relationships, i.e. does not allow identification of the more restricted clusters delineated by mitochondrial and morphological data. Had our nuclear markers displayed only one or two haplotypes per individual as expected, we could have tried to sort individuals into clusters by using population genetic models that are not hindered by shared ancestral haplotypes [57]. However, since orthology/paralogy relationships among our sequences are unclear, the actual number of copies of each marker remains unknown, and a population genetic analysis of our data is impossible.

The data presented here bring partial support to the morphological delimitation of species in Hawaiian corals of the genus Pocillopora. ITS2 and mitochondrial data concur with the delimitation of $P$. ligulata as a distinct populational unit of possible species level, whereas mitochondrial data also strongly support the distinctiveness of $P$. molokensis: these results may have significant implications regarding conservation, since 
these two morphospecies are listed as putative Hawaiian endemics [58]. However, and with regard to the high level of intra- and interpopulational variation, determining whether these Hawaiian morphological and genetic clusters may belong to more widespread genetic clusters will require further investigation. It is also unclear whether the two mitochondrial lineages identified among corals of the $P$. damicornis morphotype are two cryptic species or just an instance of intraspecific variation similar to the one previously reported for corals of the genus Montastrea [17]. Moreover, further research will be needed to clarify the status of the $P$. meandrina and $P$. eydouxi morphotypes that could only be distinguished using ITS2, not using mitochondrial markers: given our small sample size for P. eydouxi, the hypothesis that these two morphotypes may be growth forms of a single species cannot be rejected. Hence, this report is a first step toward a molecular reassessment of species boundaries in the coral genus Pocillopora, but examination of a larger number of specimens collected over the whole area of distribution of this genus will be required before more general conclusions can be reached.

\section{Acknowledgements}

Research by J.-F. Flot was supported by a PhD scholarship from the French Ministry of Research and Education and by a research grant from the MNHN program État et structure phylogénétique de la biodiversité actuelle et fossile. Support from the Consortium national de recherche en génomique is acknowledged (agreement No. 2005/67 on the project 'Macrophylogeny of life' directed by Guillaume Lecointre). This project benefited greatly from the assistance of Annie Tillier, Josie Lambourdière, and Céline Bonillo at the Service de systématique moléculaire (MNHN CNRS IFR 101). Thanks to Evelyn Cox, Frank Stanton and Daniel Thornhill for helping with sample collection during the 2002 Pauley Summer Program 'Molecular Biology of Corals'; participation of J.-F. Flot in this program was supported by the E. W. Pauley Foundation. Thanks also to Keoki Stender for providing field information, to Marie-Catherine Boisselier, Magalie Castelin, Julien Lorion, and Nicolas Puillandre for useful discussions, and to Sarah Samadi for critically reading an earlier version of this paper.

\section{References}

[1] J.E.N. Veron, Corals in Space and Time: The Biogeography \& Evolution of the Scleractinia, University of New South Wales Press, Sydney, Australia, 1995.
[2] R.H. Randall, Some problems in reef coral taxonomy, Micronesica 15 (1976) 151-156.

[3] E. Meroz, I. Brickner, Y. Loya, A. Peretzman-Shemer, M. Ilan, The effect of gravity on coral morphology, Proc. R. Soc. Lond. B 269 (2002) 717-720.

[4] S.V. Vollmer, S.R. Palumbi, Hybridization and the evolution of reef coral diversity, Science 296 (2002) 2023-2025.

[5] O. Folmer, M. Black, W. Hoeh, R. Lutz, R. Vrijenhoek, DNA primers for amplification of mitochondrial cytochrome $c$ oxidase subunit I from diverse metazoan invertebrates, Mol. Mar. Biol. Biotechnol. 3 (1994) 294-299.

[6] P.D.N. Hebert, A. Cywinska, S.L. Ball, J.R. deWaard, Biological identifications through DNA barcodes, Proc. Biol. Sci. 270 (2003) 313-321.

[7] I. Àlvarez, J.F. Wendel, Ribosomal ITS sequences and plant phylogenetic inference, Mol. Phylogenet. Evol. 29 (2003) 417-434.

[8] D. Liao, Concerted evolution: molecular mechanism and biological implications, Am. J. Hum. Genet. 64 (1999) 24-30.

[9] G. Dover, Molecular drive: a cohesive mode of species evolution, Nature 299 (1982) 111-117.

[10] D.M. Hillis, M.T. Dixon, Ribosomal DNA: molecular evolution and phylogenetic inference, Q. Rev. Biol. 66 (1991) 411-453.

[11] S. Palumbi, C. Baker, Contrasting population structure from nuclear intron sequences and mtDNA of humpback whales, Mol Biol. Evol. 11 (1994) 426-435.

[12] N. Bierne, S.A. Lehnert, E. Bédier, F. Bonhomme, S.S. Moore, Screening for intron-length polymorphisms in penaeid shrimps using exon-primed intron-crossing (EPIC)-PCR, Mol. Ecol. 9 (2000) 233-235.

[13] S.N. Jarman, R.D. Ward, N.G. Elliott, Oligonucleotide primers for PCR amplification of coelomate introns, Mar. Biotechnol. (NY) 4 (2002) 347-355.

[14] T.L. Shearer, M.J.H. van Oppen, S.L. Romano, G. Wörheide, Slow mitochondrial DNA sequence evolution in the Anthozoa (Cnidaria), Mol. Ecol. 11 (2002) 2475-2487.

[15] M. Hellberg, No variation and low synonymous substitution rates in coral mtDNA despite high nuclear variation, BMC Evol Biol. 6 (2006) 24.

[16] T. Ridgway, Testing the applicability of molecular genetic markers to population analyses of scleractinian corals, Symbiosis 33 (2002) 243-261.

[17] H. Fukami, N. Knowlton, Analysis of complete mitochondrial DNA sequences of three members of the Montastraea annularis coral species complex (Cnidaria, Anthozoa, Scleractinia), Cora Reefs 24 (2005) 410-417.

[18] L.M. Márquez, D.J. Miller, J.B. MacKenzie, M.J.H. van Oppen, Pseudogenes contribute to the extreme diversity of nuclear ribosomal DNA in the hard coral Acropora, Mol. Biol. Evol. 20 (2003) 1077-1086.

[19] S.V. Vollmer, S.R. Palumbi, Testing the utility of internally transcribed spacer sequences in coral phylogenetics, Mol. Ecol. 13 (2004) 2763-2772.

[20] M.J.H. van Oppen, B.J. McDonald, B. Willis, D.J. Miller, The evolutionary history of the coral genus Acropora (Scleractinia, Cnidaria) based on a mitochondrial and a nuclear marker: reticulation, incomplete lineage sorting, or morphological convergence? Mol. Biol. Evol. 18 (2001) 1315-1329.

[21] M.J.H. van Oppen, B.L. Willis, H. Van Vugt, D.J. Miller, Examination of species boundaries in the Acropora cervicornis group (Scleractinia, Cnidaria) using nuclear DNA sequence analyses, Mol. Ecol. 9 (2000) 1363-1373. 
[22] M.J.H. van Oppen, E.M. Koolmees, J.E.N. Veron, Patterns of evolution in the scleractinian coral genus Montipora (Acroporidae), Mar. Biol. 144 (2004) 9-18.

[23] J.E.N. Veron, M. Stafford-Smith, Corals of the World, Australian Institute of Marine Science, 2000.

[24] T. Ridgway, Allozyme electrophoresis still represents a powerful technique in the management of coral reefs, Biodivers. Conserv. 14 (2005) 135-149.

[25] G.T. Conception, M. Medina, R.J. Toonen, Noncoding mitochondrial loci for corals, Mol. Ecol. Notes 6 (2006) 1208-1211.

[26] J.-F. Flot, S. Tillier, Molecular phylogeny and systematics of the scleractinian coral genus Pocillopora in Hawaii, in: Proc. 10th Int. Coral Reef Symp. 1, 2006, pp. 24-29.

[27] C.A. Chen, C.-C. Chang, N.V. Wei, C.-H. Chen, Y.-T. Lein, H.-E. Lin, C.-F. Dai, C.C. Wallace, Secondary structure and phylogenetic utility of the ribosomal internal transcribed spacer 2 (ITS2) in scleractinian corals, Zool. Stud. 43 (2004) 759-771.

[28] J.-F. Flot, S. Tillier, The mitochondrial genome of Pocillopora (Cnidaria: Scleractinia) contains two variable regions: The putative D-loop and a novel ORF of unknown function, Gene 401 (2007) 80-87.

[29] S. Rozen, H. Skaletsky, Primer3 on the WWW for general users and for biologist programmers, in: S. Krawetz, S. Misener (Eds.), Bioinformatics Methods and Protocols: Methods in Molecular Biology, Humana Press, Totowa, NJ, USA, 2000, pp. 365-386.

[30] J.-F. Flot, A. Tillier, S. Samadi, S. Tillier, Phase determination from direct sequencing of length-variable DNA regions, Mol. Ecol. Notes 6 (2006) 627-630.

[31] J.-F. Flot, Champuru 1.0: a computer software for unraveling mixtures of two DNA sequences of unequal lengths, Mol. Ecol. Notes 7 (2007) 974-977.

[32] A. Clark, Inference of haplotypes from PCR-amplified samples of diploid populations, Mol. Biol. Evol. 7 (1990) 111-122.

[33] H. Rudi, K.-E. Gylder, O.A. Rognli, K. Rudi, Direct haplotypespecific DNA sequencing, Prep. Biochem. Biotechnol. 36 (2006) 253-257.

[34] M.P. Hare, S.R. Palumbi, The accuracy of heterozygous base calling from diploid sequence and resolution of haplotypes using allele-specific sequencing, Mol. Ecol. 8 (1999) 1750-1752.

[35] S. Kumar, K. Tamura, M. Nei, MEGA3: Integrated software for Molecular Evolutionary Genetics Analysis and sequence alignment, Brief. Bioinform. 5 (2004) 150-163.

[36] J. Rozas, J.C. Sánchez-DelBarrio, X. Messeguer, R. Rozas, DnaSP, DNA polymorphism analyses by the coalescent and other methods, Bioinformatics 19 (2003) 2496-2497.

[37] H.J. Bandelt, P. Forster, A. Röhl, Median-joining networks for inferring intraspecific phylogenies, Mol. Biol. Evol. 16 (1999) $37-48$.

[38] J.J. Doyle, The irrelevance of allele tree topologies for species delimitation, and a non-topological alternative, Syst. Bot. 20 (1995) 574-588.

[39] H. Carson, The species as a field for recombination, in: E. Mayr (Ed.), The Species Problem, American Association for the Advancement of Science, Washington, 1957, pp. 23-38.

[40] R.H. Richmond, P.L. Jokiel, Lunar periodicity in larva release in the reef coral Pocillopora damicornis at Enewetak and Hawaii, Bull. Mar. Sci. 34 (1984) 280-287.

[41] G. Muir, C.C. Fleming, C. Schlötterer, Three divergent rDNA clusters predate the species divergence in Quercus petraea (Matt.) Liebl. and Quercus robur L, Mol. Biol. Evol. 18 (2001) 112-119.

[42] C. Schlötterer, D. Tautz, Chromosomal homogeneity of Drosophila ribosomal DNA arrays suggests intrachromosomal exchanges drive concerted evolution, Curr. Biol. 4 (1994) 777783.

[43] R.J. Simpson, C.S. Wilding, J. Grahame, Intron analyses reveal multiple calmodulin copies in Littorina, J. Mol. Evol. 60 (2005) 505-512.

[44] S.C. France, N. Tachino, J. Thomas, F. Duda, R.A. Shleser, S.R. Palumbi, Intraspecific genetic diversity in the marine shrimp $\mathrm{Pe}$ naeus vannamei: multiple polymorphic elongation factor-1alpha loci revealed by intron sequencing, Mar. Biotechnol. (NY) 1 (1999) 261-268.

[45] E.A. Zimmer, S.L. Martin, S.M. Beverley, Y.W. Kan, A.C. Wilson, Rapid duplication and loss of genes coding for the alpha chains of hemoglobin, Proc. Natl Acad. Sci. USA 77 (1980) $2158-2162$.

[46] J.C. Kenyon, Models of reticulate evolution in the coral genus Acropora based on chromosome numbers: parallels with plants, Evolution 51 (1997) 756-767.

[47] J.-F. Flot, C. Ozouf-Costaz, M. Tsuchiya, R. van Woesik, Comparative coral cytogenetics, in: Proc. 10th Int. Coral Reef Symp. 1, 2006, pp. 4-8.

[48] I.B. Baums, C.R. Hughes, M.E. Hellberg, Mendelian microsatellite loci for the Caribbean coral Acropora palmata, MEPS 288 (2005) 115-127.

[49] M. Hidaka, Tissue compatibility between colonies and between newly settled larvae of Pocillopora damicornis, Coral Reefs 4 (1985) 111-116.

[50] M. Hidaka, K. Yurugi, S. Sunagawa, R.A. Kinzie, Contact reactions between young colonies of the coral Pocillopora damicornis, Coral Reefs 16 (1997) 13-20.

[51] J. Sebat, B. Lakshmi, J. Troge, J. Alexander, J. Young, P. Lundin, S. Månér, H. Massa, M. Walker, M. Chi, N. Navin, R. Lucito, J. Healy, J. Hicks, K. Ye, A. Reiner, T.C. Gilliam, B. Trask, N. Patterson, A. Zetterberg, M. Wigler, Large-scale copy number polymorphism in the human genome, Science 305 (2004) 525528.

[52] A.J. Iafrate, L. Feuk, M.N. Rivera, M.L. Listewnik, P.K. Donahoe, Y. Qi, S.W. Scherer, C. Lee, Detection of large-scale variation in the human genome, Nat. Genet. 36 (2004) 949-951.

[53] J.L. Freeman, G.H. Perry, L. Feuk, R. Redon, S.A. McCarroll, D.M. Altshuler, H. Aburatani, K.W. Jones, C. Tyler-Smith, M.E. Hurles, N.P. Carter, S.W. Scherer, C. Lee, Copy number variation: New insights in genome diversity, Genome Res. 16 (2006) 949-961.

[54] H. Magalon, M. Adjeroud, M. Veuille, Patterns of genetic variation do not correlate with geographical distance in the reefbuilding coral Pocillopora meandrina in the South Pacific, Mol. Ecol. 14 (2005) 1861-1868.

[55] H. Magalon, S. Samadi, M. Richard, M. Adjeroud, M. Veuille, Development of coral and zooxanthella-specific microsatellites in three species of Pocillopora (Cnidaria, Scleractinia) from French Polynesia, Mol. Ecol. Notes 4 (2004) 206-208.

[56] C.J. Starger, S.S.R. Yeoh, C.-F. Dai, A.C. Baker, R. DeSalle, Ten polymorphic STR loci in the cosmopolitan reef coral, Pocillopora damicornis, Mol. Ecol. Notes, in press, doi:10.1111/j.14718286.2007.02017.x.

[57] J.K. Pritchard, M. Stephens, P. Donnelly, Inference of population structure using multilocus genotype data, Genetics 155 (2000) 945-959.

[58] J.E. Maragos, Revised checklist of extant shallow-water stony coral species from Hawaii (Cnidaria: Anthozoa: Scleractinia), Bishop Mus. Occas. Pap. 42 (1995) 54-55. 